\title{
結合法による弾性支承を有する連続ばりの動的解析
}

\section{A DYNAMIC ANALYSIS OF CONTINUOUS BEAMS ON ELASTIC SUPPORTS}

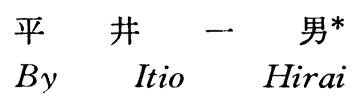

要 旨この研究は, 変位・回転に対して抵抗を持 つ弾性支承上の連続ばりの固有振動数・振動モードを結 合法によって求める方法について述べたものである。こ の方法は, 一本の連続したはりに中間支点や弾性支承を 逐次絬合してゆく方法であり,さらにこのはりの両端を 他の部材や支点に結合することも可能である。

\section{1. 緒論}

筆者は, 結合法によるランガー桁橋や不整格子桁の動 的解析をすでに発表している(1),2)が，ここでは同様の手 法すなわち結合法によって, 変位あるいは回転に対して 抵抗を持つ弾性支承上の連続ばりの固有振動数・振動モ 一ドを求める方法について述べる。一般に構造物の固有 振動数・振動モードが与えられるならば, その動的レス ポンスの解析は可能であるから,この論文では主題のは りの固有振動数・振動モードを求める方法について主と して発表する。

ここでいう弾性支承とは, 変形に比例した抵抗を生じ る支承であり，今後変位・回転に刘して抵抗を持つ支承 をそれぞれ変位支承・回軽支承と呼ぶことにする。この 種のはりは静力学的には多く取り扱われているけれど も, 動力学的解析はほとんど行なわれていないようであ る。その動力学的解析の一つとして振動たわみ角法" 適用が考えられるが，ここでは結合法と呼ぶ解析法を使 用した。すなわち，連続ばりを1本のはりと考え，この 1本のはりに各支承を，その支承条件を満足するように 順次結合して基礎式を誘導する方法をとった。振動たわ み角法でははりを各スパンごとに切断し，その両端と支 承との間に㧍ける変形の条件と力の平衡条件とを考党て 式を誘導する必要があるが，上に述べた解析法による と，単に連続した 1 本のはりに支承を結命することのみ を考えて基礎式をたてることができるから，考え方が非 常に簡明になる。このように1本のはりに支承を結合し てゆくのでこの解析法を結合法と名つけけいる。はりと 全支承との結合は必ずしも同時に行なわなくてよいので あって, 数值計算の可能な範用に拾いて順次結合して解 析を進めてゆけばよい。特に支承が多い場合には，はり 全体を適当なグループに分割し，各グループについて上 述の解析を逐次行ない，最後にそれらの雨端を結合し

* 正員 熊本大学助教授 工学部応用力学教室
て，与えられた連続ばりに組み立てることもできる。

また，振動たわみ角法によって求めた振動モードは, 各スパンごとに異なった式であらわされるが, 結合法に よると全スパンにわたり一つの式で与えられる。したが って, 走行荷重をうけるはりのレスポンスの解析のと き4，振動たわ及角法ではスパンごとに異なった関数・ 初期条件を使用して数值計算を行なろ必要が生じるが, 結合法では振動モードが一つの関数であらわされるから 前者のような不便が除かれる。な拉, 結合法によると振 動モードを正規化するさい, その係数がきわめて容易に 求められる点で特にすぐれていると思う。

\section{2. 理論}

固有振動数と振動モードに関する一般理論を述べるま えに, 動荷重をうけるはりの基礎式と主要な記号を(1)， (2) に颃いて述べる。

（1）動的集中荷重をうけるはりのたわみとたわみ角 筆者は,さきに図-1 と示すはりの固有振動数 $\omega_{m}$ ・

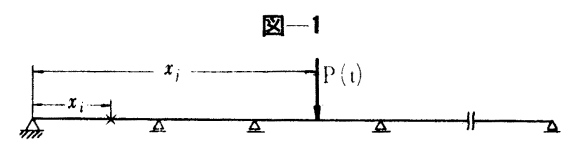

正規化した振動モード $\Phi_{m}(x)$ を求めることができたな らば，集中荷重 $P(t)$ が $x=x_{j}$ なる点に作用するとき, $x=x_{i}$ 点の測定点に枌けるたわみのレスポンス $V\left(x_{i}, t\right)$ は式 (1),(2) にて求めることができることを述べた"。

$$
\begin{aligned}
& \ddot{v}_{m}+\omega_{m}{ }^{2} v_{m}=\Phi_{m}\left(x=x_{i}\right) \Phi_{m}\left(x=x_{j}\right) P(t) . \\
& V\left(x_{i}, t\right)=\sum_{m=1}^{\infty} v_{m} \ldots \ldots \ldots \ldots \ldots \ldots \ldots \ldots \ldots \ldots \ldots \ldots \ldots \ldots \ldots \ldots \ldots \ldots \ldots \ldots \ldots
\end{aligned}
$$

ここに

$v_{m}: m$ 次の振動モード $\Phi_{m}(x)$ に対応する振動の大き ¿

$\omega_{m}: m$ 次の固有振動数

$\varphi_{m}(x): m$ 次の振動モ一ド

$\Phi_{m}(x):$ 正規化した $m$ 次の振動モード $\left(c_{m} \varphi_{m}(x)=\right.$ $\left.\Phi_{m}(x)\right)$

$\Phi_{m}(x)$ は正規化条件式

$$
\int_{l} \rho \Phi_{m}^{2}(x) d x=1 .
$$

を満足する。ただし

$\rho:$ はのの単位長さあたりの質量 
単純ばりの場合には

$$
\begin{aligned}
& \omega_{m}=\left(\frac{m \pi}{l}\right)^{2} \sqrt{\frac{E I}{\rho}} \cdots \cdots \\
& \Phi_{m}(x)=\sqrt{\frac{2}{M}} \sin \frac{m \pi x}{l}
\end{aligned}
$$

ここに

$$
l: \text { スパン }
$$

$M:$ はりの全質量

また，たわみ角 $\theta\left(x_{i}\right)$ は式 (6) とより求めることが できる。

$$
\theta\left(x_{i}, t\right)=\frac{\partial V\left(x_{i}, t\right)}{\partial x_{i}}=\sum_{m=1}^{\infty} \frac{\partial v_{m}}{\partial x_{i}}
$$

定常強制力 $P(t)=P_{0} \sin \omega t$ が作用するときには式 (1) は式 (7) となる。

$$
v_{m}=\Omega_{m} \Phi_{m}\left(x=x_{i}\right) \Phi_{m}\left(x=x_{j}\right) P_{0} \sin \omega t
$$

ここに

$$
\Omega_{m}=1 /\left\{\omega_{m}^{2}-\omega^{2}\right\}
$$

強制周期力 $P=P_{0} \sin \omega t$ が作用するとき, その荷重点・ 測定点の座標が与兄られたならば，任意の測定点のたわ み $V\left(x_{i}, t\right)$, たわ久角 $\theta\left(x_{i}, t\right)$ はそれぞれ式 (2) と (7), （6）により求めることができるから，図一2 と示すよう

\section{図-2}

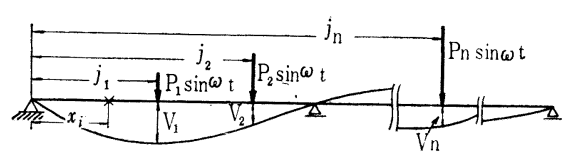

な $\boldsymbol{n}$ 個の強制周期力が作用するとき，測定点 $x_{\boldsymbol{i}}$ 飞打け るたわみは式 (8) とより与兄らる。

$$
\begin{aligned}
V\left(x_{i}\right)= & \sum_{m=1}^{\infty} \Omega_{m} \Phi_{m}\left(x_{i}\right)\left\{\Phi_{m}\left(j_{1}\right) P_{1}\right. \\
& \left.+\Phi_{m}\left(j_{2}\right) P_{2}+\cdots \cdots \Phi_{m}\left(j_{n}\right) P_{n}\right\}
\end{aligned}
$$

ここル

$$
\Phi_{m}\left(j_{j}\right)=\Phi_{m}\left(x=j_{j}\right), \Phi_{m}\left(x_{i}\right)=\Phi_{m}\left(x=x_{i}\right)
$$

( $j$ の添字は荷重点番号を示す)

ただし，ここで考党ている集中荷重 $P_{i} \sin \omega t$ は同一位 相の周期力であるから, $\sin \omega t=1$ 亿抢ける瞬間のみに ついて考光, 式の表現を簡単にした。この論文に打いて 取り扱う荷重はすべて周期力であるから, 上記のように 以下の式の表現をる簡単化するが，このようと表現すれ ば, 式 (2),(6) は式 $(2)^{\prime},(6)^{\prime}$ のように書ける。

$$
\begin{aligned}
V\left(x_{i}\right) & =\sum_{m=1}^{\infty} v_{m} \\
\theta\left(x_{i}\right) & =\frac{d V\left(x_{i}\right)}{d x_{i}}=\sum_{m=1}^{\infty} \frac{d v_{m}\left(x_{i}\right)}{d x_{i}} \\
& =\sum_{m=1}^{\infty} \Omega_{m} \Phi_{m}{ }^{\prime}\left(x_{i}\right) \Phi_{m}\left(x=x_{j}\right) P_{0}
\end{aligned}
$$

また，図一2 と示すはりのたわ及角 $\theta\left(x_{i}\right)$ は式 (8) 上 り式 (9) とて与兄られる。

$$
\begin{aligned}
\theta\left(x_{i}\right)= & \sum_{m=1}^{\infty} \Omega_{m} \Phi_{m}\left(x_{i}\right)\left\{\Phi_{m}\left(j_{1}\right) P_{1}\right. \\
& \left.+\Phi_{m}\left(j_{2}\right) P_{2}+\cdots \cdots \Phi_{m}\left(j_{n}\right) P_{n}\right\}
\end{aligned}
$$

したがって, 図一2 の載荷点に括けるたわみ $V_{1}, V_{2}, \cdots$ $\cdots, V_{n}$, たわみ角 $\theta_{1}, \theta_{2}, \cdots \cdots, \theta_{n}$ は式 (10),(11) 飞て あらわされる。

$$
\left.\begin{array}{c}
V_{1}=a_{11} P P_{1}+a_{12} P P_{2}+\cdots \cdots a_{1 n} P P_{n} \\
V_{2}=a_{21} P P_{1}+a_{22} P P_{2}+\cdots \cdots a_{2 n} P P_{n} \\
V_{n}=a_{n 1} P P_{1}+a_{n 2} P P_{2}+\cdots \cdots a_{n n} P P_{n}
\end{array}\right\}
$$

ここに

$$
\begin{aligned}
& a_{i j} P=\sum_{m=1}^{\infty} \Omega_{m} \Phi_{m}\left(x_{i}\right) \Phi_{m}\left(j_{j}\right), \quad(i, j=1,2,3, \cdots, n) \\
& \theta_{1}=b_{11} P P_{1}+b_{12} P P_{2}+\cdots \cdots b_{1 n} P P_{n} \\
& \theta_{2}=b_{21} P P_{1}+b_{22} P P_{2}+\cdots \cdots b_{2 n} P P_{n}
\end{aligned}
$$

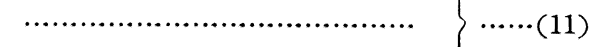

$$
\begin{aligned}
& \theta_{n}=b_{n 1} P P_{1}+b_{n 2} P P_{2}+\cdots \cdots b_{n n} P P_{n}
\end{aligned}
$$$$
\text { ここマ }
$$

$$
b_{i j} P=\sum_{m=1}^{\infty} \Omega_{m} \Phi_{m}\left(x_{i}\right) \Phi_{m}\left(j_{j}\right), \quad(i, j=1,2,3, \cdots, n)
$$

\section{（2）動的モーメント荷重をうけるはりのたわみと たわみ角}

図一3（a）に示すはりに動的モーメント荷重が作用す るとき，このモーメント荷重は図一3 (b) そ示すように

\section{图-3}

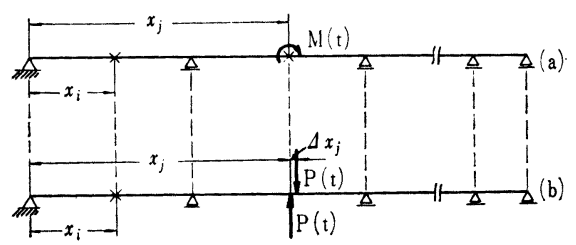

微小な距離 $\Delta x_{j}$ に作用する偶力として置き換えること ができる。このようにモーメント荷重を 2 つ集中荷重 として等価的にあらわすならば，このときのたわみは， 式 (1) の関係がそのまま使用できて次式が成立する。

$$
\begin{array}{r}
\ddot{z}_{m}+\omega_{m}^{2} v_{m}=\Phi_{m}\left(x_{i}\right)\left\{\Phi_{m}\left(x_{j}+\Delta x_{j}\right)-\Phi_{m}\left(x_{j}\right)\right\} P(t) \\
=\Phi_{m}\left(x_{i}\right)\left\{\frac{\Phi_{m}\left(x_{j}+\Delta x_{j}\right)-\Phi_{m}\left(x_{j}\right)}{\Delta x_{j}}\right\} P(t) \cdot \Delta x_{j} \\
=\Phi_{m}\left(x_{i}\right) \Phi_{m}{ }^{\prime}\left(x_{j}\right) M(t) \cdots \cdots \ldots \ldots \ldots \ldots \ldots \ldots(12)
\end{array}
$$

すなわちモーメント荷重が作用するときはりと生じるた わみを求めるには，集中荷重が作用するときのたわ及を 求める式 (1) 飞括いて, 単に $\Phi_{m}\left(x_{j}\right)$ のかわりに $\Phi_{m}{ }^{\prime}$ $\left(x_{j}\right)$, 荷重 $P(t)$ のかわりにモーメント荷重 $M(t)$ と置 けばよいことがわかる。

また，たわ久角 $\theta\left(x_{i}\right)$ は式 (6) がそのまま使用でき る。集中荷重の場合に招けると同様に, この論文中に括 いて作用させるモーメント荷重は定常周期モーメント荷 重のみであるから， $M \sin \omega t$ の代りと $M$ または $M(t)$ と書くことにする。

図一3 (a) のはりにモーメント荷重 $M$ が作用すると き, $x=x_{i}$ 点のたわみは次式にてあらわされる。 


$$
V\left(x_{i}\right)=\sum_{m=1}^{\infty} \Omega_{m} \Phi_{m}\left(x_{i}\right) \Phi_{m}{ }^{\prime}\left(x_{j}\right) M
$$

また，たわみ角 $\theta\left(x_{i}\right)$ は式 (14) にて与えられる。

$$
\theta\left(x_{i}\right)=\sum_{m=1}^{\infty} \Omega_{m} \Phi_{m}^{\prime}\left(x_{i}\right) \Phi_{m}^{\prime}\left(x_{j}\right) M
$$

したがって, 図-4 に示すように $n$ 個のモーメント荷重 図-4

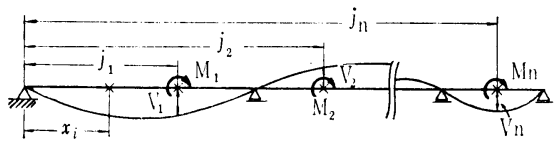

が作用するとき， $x=x_{i}$ 点のたわみ $V\left(x_{i}\right)$ ，たわ久角 $\theta\left(x_{i}\right)$ は式 (15),(16) にてあらわされる。

$$
\begin{aligned}
V\left(x_{i}\right)= & \sum_{m=1}^{\infty} \Omega_{m} \Phi_{m}\left(x_{i}\right)\left\{\Phi_{m}{ }^{\prime}\left(j_{1}\right) M_{1}\right. \\
& \left.+\Phi_{m}{ }^{\prime}\left(j_{2}\right) M_{2}+\cdots \cdots \Phi_{m}\left(j_{n}\right) M_{n}\right\} \cdots \\
\theta\left(x_{i}\right)= & \sum_{m=1}^{\infty} \Omega_{m} \Phi_{m}{ }^{\prime}\left(x_{i}\right)\left\{\Phi_{m}{ }^{\prime}\left(j_{1}\right) M_{1}\right. \\
& \left.+\Phi_{m}\left(j_{2}\right) M_{2}+\cdots \cdots \Phi_{m^{\prime}}\left(j_{n}\right) M_{n}\right\} \cdots
\end{aligned}
$$

また, 載荷点机けるたわみ $V_{1}, V_{2}, \cdots \cdots, V_{n}$, たわみ 角 $\theta_{1}, \theta_{2}, \cdots \cdots, \theta_{n}$ は式 (17),(18) にて示される。

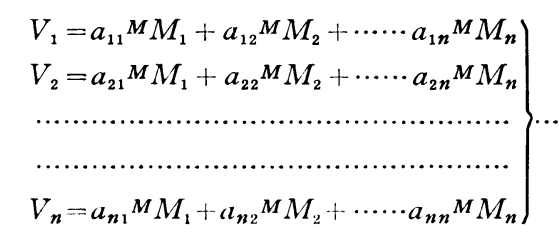

ただし

$$
\begin{aligned}
& a_{i j}{ }^{M}=\sum_{m=1}^{\infty} \Omega_{m} \Phi_{m}\left(x_{i}\right) \Phi_{m}{ }^{\prime}\left(j_{j}\right) \\
& \theta_{1}=b_{11}{ }^{M} M_{1}+b_{12}{ }^{M} M_{2}+\cdots \cdots b_{1 n}{ }^{M} M_{n} \\
& \theta_{2}=b_{21} M_{1}+b_{22}{ }^{M} M_{2}+\cdots \cdots b_{2 n}{ }^{M} M_{n}
\end{aligned}
$$

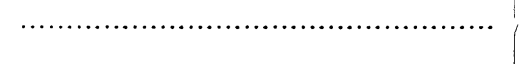

ただし

$$
\theta_{n}=b_{n 1} M M_{1}+b_{n 2} M M_{2}+\cdots \cdots b_{n n} M M_{n}
$$

$$
b_{i j} M=\sum_{m=1}^{\infty} \Omega_{m} \Phi_{m}{ }^{\prime}\left(x_{i}\right) \Phi_{m}{ }^{\prime}\left(j_{j}\right)
$$

\section{（3）連続ばりの自由振動}

従来, 連続ばりの固有振動数・振動モードを決定する には, 各支点上の左右のたわみ角・端モーメントが等し いという条件が用いられてきた。このような方法では， 基礎式は比較的簡単にたてることができても, 数值計算 にはかなりの単力を要する。以下に述べる方法による 方 $^{5), 6)}$ が便利である。

図一5 (a) に示寸連続ばりについて考光る。図一5 (b) に示すように，まず中間支点を取り去った単純ばりに集 中荷重 $P_{1}, P_{2}, \cdots \cdots, P_{n}$ を中間支点に作用させる。この時 の載荷点のたわみ $V_{1}, V_{2}, \cdots \cdots, V_{n}$ は式 (10), (4),(5) により求められる。しかるに与兄られた連続ばり上の中 間支点では

$$
V_{1}=V_{2}=\cdots \cdots=V_{n}=0
$$

図-5

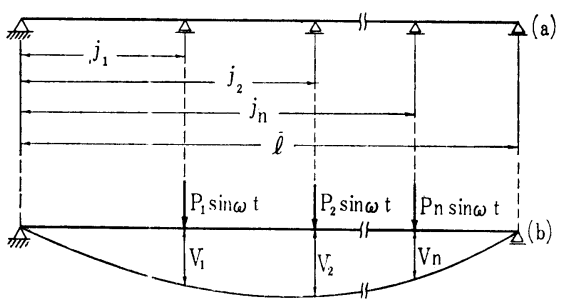

である。すなわも式 (19) が得られる。

$$
\begin{aligned}
& a_{11} P P_{1}+a_{12} P P_{2}+\cdots \cdots a_{1 n} P P_{n}=0 \\
& a_{21} P P_{1}+a_{22} P P_{2}+\cdots \cdots a_{2 n} P P_{n}=0
\end{aligned}
$$

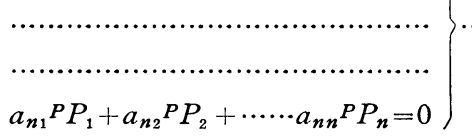

すべてが 0 でない $P_{i},(i=1,2, \cdots \cdots, n)$ の值に対して上 式が成立するためには式 (20) が必要である。

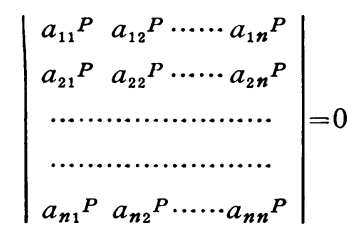

上式は連続ばりの振動数方程式にほかならない。式 (20) 上り得られた固有振動数 $\omega_{c},(c=1,2,3, \cdots \cdots, \infty)$ の值 を式 (19) に代入すれば， $P_{1}, P_{2}, \cdots \cdots, P_{n}$ の比が決定で きる。この比を式 (8) に代入すれば, 連続ばりの振動モ 一ド $\varphi_{c}(x)$ が決定できる。単純ばりの振動モード $\Phi_{m}(x)$ は式 (5) により与污られる正弦波関数であるから, 上述

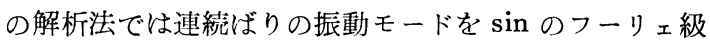
数に展開したことになる。いまこれを次式のように書け たとする。

$$
\varphi_{c}(x)=d_{1} \sin \frac{\pi x}{l}+d_{2} \sin \frac{2 \pi x}{l}+\cdots
$$

この正規化した振動モード $\Phi_{c}(x)$ は次式により求める ことができる。

$$
\Phi_{c}(x)=\sqrt{\frac{2}{M} \cdot \frac{1}{d_{1}{ }^{2}+d_{2}^{2}+\cdots}}\left(\sum_{i=1}^{\infty} d_{i} \sin \frac{i \pi x}{l}\right)
$$

上に述ベた方法汭よると, 正規化モード $\Phi_{c}(x)$ を式 (22) の簡単な式で決定できる点がとくにすぐれている と思う。さらに, 従来の解析法 ${ }^{3)}{ }^{7)}$ では, 振動モード $\Phi_{c}$ (x) の関数は, 各スパンごとに異なったものとなるが, この方法によると全スパンにわたって一つの関数で表示 できる。一般にはりが走行荷重をうけるとき,そのレスポ ンスを求める運動方程式は, 式 (1) に挌いて単に荷重点 の座標を時間の関数として $x_{j}=x_{j}(t)$ と打けばよい4。 すなわち,

$$
\ddot{v}_{m}+\omega_{m}{ }^{2} v_{m}=\Phi_{m}\left(x_{i}\right) \Phi_{m}\left\{x_{j}=x_{j}(t)\right\} P(t) \cdots(23)
$$

たとえば, 荷重が $a$ の地点より初速度 $v_{0}$, 加速度 $\boldsymbol{u}$ で 移動を開始したとすると， $x_{j}(t)$ は式 (24) により与え 
られる。

$$
x_{j}(t)=a+v_{0} t+0.5 u t^{2}
$$

したがって, 振動モードがスパンごとに異なった関数で あらわされていると, スパンごとに初期条件を与え, 異 なった基礎式を解く必要があるが, 振動モードがスパン 全体にわたり一つの関数によって与えられていると, こ のような不便がなくなり, 数值計算を容易に行なうこと ができる。

\section{（4）弾性支承を有する連続ばりの自由振動}

ここで述べる弾性支承は, 変位に対して抵抗を持つ支 承と回転に対して抵抗を持つ支承とである。両方の場合 とも変形に比例した抵抗を持つものとする。なお, 最後 に変位・回転ともに抵抗を有する支承についても解析を 行なった。

a）変位支承を有する場合 図一6 (a) に示す連続ば りについて考える。直接この振動系の固有振動数・振動 モードを求めるにはかなり複雑な解析を必要とするの で, ここではこの系の支持条件を順次満足させながら解 析を進める方法をとる。

\section{図一6}

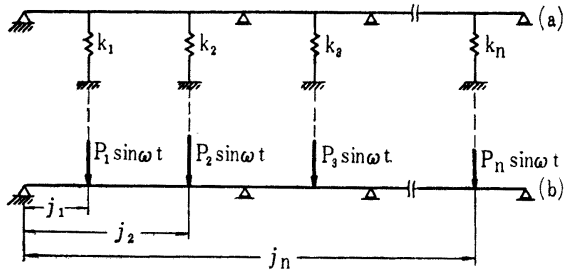

まず図一6 (b) に示すように変位支㴍を取り去った連 続ばりについて考える。この連続ばりの固有振動数 $\omega_{c}$ • 振動モ一ド $\Phi_{c}(x)$ は (3) で述べた方法により求めるこ とができる。この $\Phi_{c}(x)$ は原振動系（a図）の中間支 点の条件を満足しているから，この $\Phi_{c}(x)$ を用い，こ れに弾性支持の条件を満足させることを考える。

いま, この連続ばりの変位支承のあった点隹中荷重 $P_{i} \sin \omega t,(i=1,2,3, \cdots \cdots, n)$ を作用させる（b図）。こ のとき荷重点のたわみ $V_{1}, V_{2}, \cdots \cdots, V_{n}$ は式 (10) 飞よ り求めることができる。ここに

$$
a_{i j}=\sum_{c=1}^{\infty} \frac{1}{\omega_{c}^{2}-\omega^{2}} \Phi_{c}\left(x_{i}\right) \Phi_{c}\left(j_{j}\right)
$$

変位支承のバネ常数を $k_{i},(i=1,2, \cdots \cdots, n)$ とすると 荷重と変形との関係は次式によりあらわされる。

$$
V_{i}=P_{i} s / k_{i}=k_{i}{ }^{\prime} P_{i} s,(i=1,2, \cdots \cdots, n) \cdots
$$

図一6 (b) に示す連続ばりに集中荷重 $P_{i}$ を作用させた とき, その荷重点に和ける変位と荷重との関係は式 (10) により与えられる。この連続ばりに式（25）の関係を持 つ変位支承を結合すれば，図一6 (a) の原系ができる。 このためには，両者の変位を等しく置く必要があるが, これは式 (10) と式 (25) とを等置することにより満足 できる。このようにしてでき上がった与系には，そのバ
ネとの接合点部に抏い

$$
P_{i}+P_{i} s=P_{i}, \quad(i=1,2, \cdots \cdots, n)
$$

によりあらわされる外力が作用していることになる。自 由振動している時には外力は0であるはずであるから， 式 (26) は式 (27) となる。

$$
P_{i}+P_{i} s=0
$$

上記の関係を式 (10) と式（25）とを等置したものに代 入すると次式を得る。

$$
\begin{aligned}
& \left(a_{11}{ }^{P}+k_{1}{ }^{\prime}\right) P_{1}+a_{12}{ }^{P} P_{2}+\cdots \cdots \cdots \cdots \cdot a_{1 n} P^{P} P_{n}=0 \\
& a_{21}{ }^{P} P_{1}+\left(a_{22}{ }^{P}+k_{2}{ }^{\prime}\right) P_{2}+\cdots \cdots \cdots \cdots \cdot a_{2 n}{ }^{P} P_{n}=0 \\
& \left.a_{n 1} P P_{1}+a_{n 2} P P_{2}+\cdots \cdots \cdots\left(a_{n n} P+k_{n}{ }^{\prime}\right) P_{n}=0\right)
\end{aligned}
$$

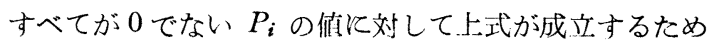
にはその係数行列が0でなければならない。すなわち

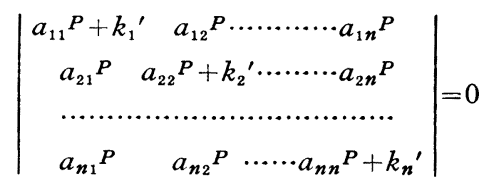

式 (29) は振動数方程式にほかならない。式 (29) より得 られた固有振動数 $\omega_{s},(s=1,2, \cdots \cdots, \infty)$ の值を式 (28) に代入すると $P_{1}, P_{2}, \cdots \cdots, P_{n}$ の比が決定できるから， これを式 (8) に代入すると振動モード $\varphi_{s}(x)$ が決定で きることになる。ただし, 式 (8) に批る $\omega_{m}, \Phi_{m}\left(x_{i}\right)$ には式 (20) より得られる連続ばりの固有振動数 $\omega_{c}$, 式 (22) Kより与えられる振動モード $\Phi_{c}(x)$ を使用する。

b) 回転支承有する場合 図一7（a）に示す連続ば りについて考える。ただし，この回転支承は回転剛性の みを有し, 鉛直方向の変位に刘しては自由に変形しろる ものとする。

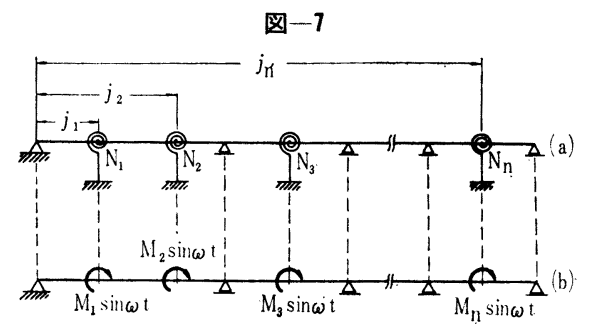

いま，この回転支承を切り離し，中間支点のみを有す る連続ばり（図一7 (b)) について考兄る。この連続ばり の，もと回転支承のあった筒所に図一7 (b) 飞示すよう な周期モーメント荷重 $M_{i} \sin \omega t,(i=1,2, \cdots, n)$ を作用 させ, このときのたわみ角を求めることについて考えて みる。この連続ばりの固有振動数 $\omega_{c}$, 振動モード $\Phi_{c}(x)$ を使用すれば，載荷点のたわ久角 $\theta_{i},(i=1,2, \cdots \cdots, n)$ とモーメント荷重との関係は式（18）にて与えられる。 ただし

$$
b_{i j}{ }^{M}=\sum_{c=1}^{\infty} \frac{1}{\omega_{c}^{2}-\omega^{2}} \Phi_{c}^{\prime}\left(x_{i}\right) \Phi_{c}^{\prime}\left(j_{j}\right)
$$


回転支承の回転剛性を $N_{i}$ とすれば, モーメント荷重 と回転角との関係は式 (30) にてあらわされる。

$$
\theta_{i}=N_{i} M_{i} s
$$

(4) a) 飞扔いて述べたと同様の解析手法をとると, 回 転支承と連続ばりとが結合できて式 (31) が得られ，さ らに振動数方程式は式 (32) に上り与えられる。

$$
\begin{aligned}
& \left(b_{11} \boldsymbol{M}+N_{1}\right) M_{1}+b_{12} \boldsymbol{M}^{M}+\cdots \cdots b_{1 n} M^{M} M_{n}=0 \\
& b_{21} M M_{1}+\left(b_{22} M+N_{2}\right) M_{2}+\cdots \cdots b_{2 n} M M_{n}=0 \\
& b_{n_{1}} M M_{1}+b_{n 2} M_{2}+\cdots \cdots\left(b_{n n} M+N_{n}\right) M_{n}=0
\end{aligned}
$$

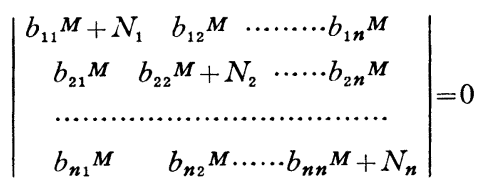

式 (32) より得られた固有振動数 $\omega_{q},(q=1,2, \cdots \cdots$, の) の值を式 (31) に代入すれば $M_{i},(i=1,2, \cdots \cdots, n)$ の比が求められるから, この比を式 (15) 飞代入して振 動モード $\varphi_{q}(x)$ が決定できる。ただし, 式 (15)の $\Omega_{m}$, $\Phi_{m}\left(x_{i}\right)$ には連続ばりの $\omega_{c}, \Phi_{c}\left(x_{i}\right)$ を使用する。 c）変位・回転に対して抵抗を持つ場合 図一8(a) に示す連続ばりについて考える。この弾性支承は変位・ 回転ともに抵抗を有するものであり，その剛性を a), b) 飞述べた $k_{i}{ }^{\prime}, N_{i},(i=1,2, \cdots \cdots, n)$ 飞てあらわすことに する。

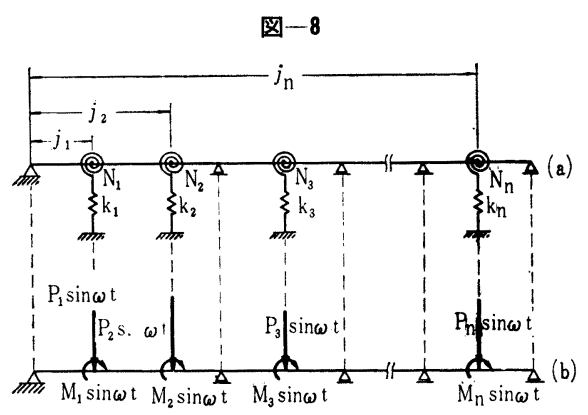

(1) 第 1 法：まず図一8 (b) に示すように弾性支承を 取り除いた連続ばりに集中荷重 $P_{i} \sin \omega t, M_{i} \sin \omega t$, $(i=1,2,3, \cdots \cdots, n)$ を作用させる。このとき載荷点のた わみ $V_{1}, V_{2}, \cdots \cdots, V_{n}$, たわみ角 $\theta_{1}, \theta_{2}, \cdots \cdots, \theta_{n}$ は式 (10), (11), (17), (18) より求められる。

$$
\begin{aligned}
& V_{1}=a_{11}{ }^{P} P_{1}+P_{12} P P_{2}+\cdots \cdots a_{1 n}{ }^{P} P_{n}+a_{11} M^{M} M_{1}+a_{12}{ }^{M} M_{2}+\cdots \cdots a_{1 n} M^{M} \\
& V_{2}=a_{21}{ }^{P} P_{1}+a_{22}{ }^{P} P_{2}+\cdots \cdots a_{2 n} P P_{n}+a_{21} M^{M} M_{1}+a_{22}{ }^{M} M_{2}+\cdots \cdots a_{2 n} M_{n} \\
& V_{n}=a_{n 1} P P_{1}+a_{n 2} P P_{2}+\cdots \cdots a_{n n} P P_{n}+a_{n 1}{ }^{M} M_{1}+a_{n 2}{ }^{M} M_{2}+\cdots \cdots a_{n n} M^{M} M_{n} \\
& \theta_{1}=b_{11} P P_{1}+b_{12} P P_{2}+\cdots \cdots b_{1 n} P P_{n}+b_{11} M^{M} M_{1}+b_{12} M^{M} M_{2}+\cdots \cdots b_{1 n} M_{n} \\
& \theta_{2}=b_{21} P P_{1}+b_{22} P P_{2}+\cdots \cdots b_{2 n} P P_{n}+b_{21} M^{M} M_{1}+b_{22}{ }^{M} M_{2}+\cdots \cdots b_{2 n}{ }^{M} M_{n}
\end{aligned}
$$

ここに

$$
\begin{aligned}
& a_{i j} P=\sum_{c=1}^{\infty} \frac{1}{\omega_{c}^{2}-\omega^{2}} \cdot \Phi_{c}\left(x_{i}\right) \Phi_{c}\left(j_{j}\right) \\
& b_{i j} P=\sum_{c=1}^{\infty} \frac{1}{\omega_{c}^{2}-\omega^{2}} \cdot \Phi_{c}^{\prime}\left(x_{i}\right) \Phi_{c}\left(j_{j}\right) \text {, } \\
& a_{i j} M=\sum_{c=1}^{\infty} \frac{1}{\omega_{c}^{2}-\omega^{2}} \cdot \Phi_{c}\left(x_{i}\right) \Phi_{c}^{\prime}\left(j_{j}\right) \text {, } \\
& b_{i j} M=\sum_{c=1}^{\infty} \frac{1}{\omega_{c}^{2}-\omega^{2}} \cdot \Phi_{c}^{\prime}\left(x_{i}\right) \Phi_{c}^{\prime}\left(j_{j}\right) \\
& \begin{array}{l}
a_{11} P_{1}+a_{12} P P_{2}+\cdots \cdots a_{1 n} P P_{n}+a_{11} M M_{1}+a_{12}{ }^{M} M_{2}+\cdots \cdots a_{1 n}{ }^{M} M_{n}=0 \\
a_{21}{ }^{P} P_{1}+a_{22} P_{2}+\cdots \cdots a_{2 n} P P_{n}+a_{21}{ }^{M} M_{1}+a_{22} M_{2}+\cdots \cdots a_{2 n} M M_{n}=0
\end{array} \\
& a_{n 1} P P_{1}+a_{n 2} P P_{2}+\cdots \cdots a_{n n} P_{n}+a_{n_{1}} M M_{1}+a_{n_{2}} M M_{2}+\cdots \cdots a_{n n} M M_{n}=0 \\
& b_{11}{ }^{P} P_{1}+b_{12} P P_{2}+\cdots \cdots b_{1 n} P P_{n}+b_{11} M_{1}+b_{12}{ }^{M} M_{2}+\cdots \cdots b_{1 n} M^{M} M_{n}=0 \\
& b_{n 1} P P_{1}+b_{n_{2}} P P_{2}+\cdots \cdots b_{n n} P P_{n}+b_{n 1} M M_{1}+b_{n 2}{ }^{M} M_{2}+\cdots \cdots b_{n n} M_{n}=0
\end{aligned}
$$

$\omega_{c}:$ 連続ばりの固有振動数

$\Phi_{c}(x):$ 連続ばりの正規化した振動モード

図一8（b）の連続ばりに集中荷重・モーメント荷重が 作用するときのたわみ・たわみ角が上式により求めるこ とができるから，a）に拈いて述べた解析手法をここで くり返して弾性支䐆を連続ばりに結合すると式 (34) が 得られ, さらに与系 (図一8 (a)) の固有振動数を式 (35) により求めることができる。

ここに

$$
a_{i i}=a_{i i}{ }^{P}+k_{i}{ }^{\prime}, b_{i i}=b_{i i}{ }^{M}+N_{i}, \quad(i=1,2, \cdots \cdots, n)
$$




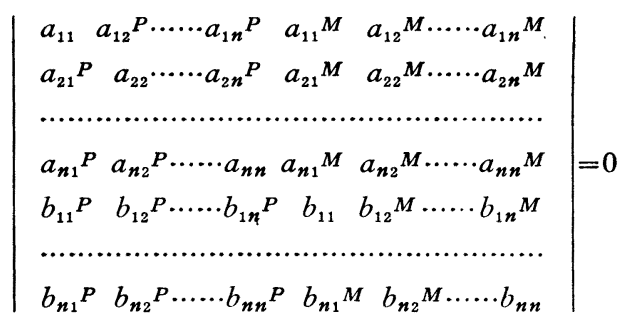

式 (35) より得られた固有振動数 $\omega_{k},(k=1,2, \cdots \cdots$, の) の值を式 (34) 飞代入すれば $P_{i}, M_{i}$ の比を決定す ることができる。一方，連続ばりと集中荷重・モーメン 卜荷重が作用するときのたわみは式（8），(15）上り次式 とてあらわされる。

$$
\begin{aligned}
V\left(x_{i}\right)= & \sum_{c=1}^{\infty} \Omega_{c} \Phi_{c}\left(x_{i}\right)\left[\left\{\Phi_{c}\left(j_{1}\right) P_{1}+\Phi_{c}\left(j_{2}\right) P_{2}\right.\right. \\
& \left.+\cdots \cdots \Phi_{c}\left(j_{n}\right) P_{n}\right\}+\left\{\Phi_{c^{\prime}}\left(j_{1}\right) M_{1}\right. \\
& \left.\left.+\Phi_{c}^{\prime}\left(j_{2}\right) M_{2}+\cdots \cdots \Phi_{c}^{\prime}\left(j_{n}\right) M_{n}\right\}\right] \cdots
\end{aligned}
$$

式 (36) 飞上で求めた $P_{i}, M_{i}$ の比を代入すれば振動モ 一ド $\varphi_{k}(x)$ が決定できる。

(2) 第 2 法: 第 1 法飞括いては, 弹幽:支承上の変位・ 回転の条件を同時に満足するよろにして解析を行なった が, 第 2 法では変位・回転の条件を逐次満足させる方法 を採ろろ。

与兄られた図一8 (a) の振動系比沏いて，まず回転抵 抗が 0 すなわち $N_{1}=N_{2}=\cdots \cdots=N_{n}=0$ なる系（図一 6 (a) と等価な系) とついて考光る。この系の固有振動 数 $\omega_{s}$ ・振動モード $\Phi_{s}(x)$ は，(4) a) に扮いて述へた方 法により求めることができる。この $\omega_{s}, \Phi_{s}(x)$ 亿回転剛 性の条件を入れれば目的が達せられるが，これは (4) b) 飞述べた式に扔いて, たんに $\omega_{c}, \Phi_{c}(x)$ のかわりに $\omega_{s}$, $\Phi_{s}(x)$ と置き換えればよいことはただちと理解できる。 この方法によると，中間支点の条件は $\omega_{c}, \Phi_{c}(x)$ により 満足され, これと変位抵抗の条件を満足させ, 最後に回 転抵抗の条件を満足させることになり，単純支持・変位・ 回転の条件を逐次満足させたことになる。第 1 法に括い ては一つの弾性支承に対して 2 個の未知数を必要とする から， $n$ 個の弾性支承点を持つ場合飞は $2 n$ 個の未知数 となる。したがって, $n$ が大きい值のときには, 式 (34), （35）などの数值計算には大変な学力を要するが, 第 2 法 そよれば， $n$ 個の未知数のものについて 2 回計算すれば よいことになるから，計算はかなり容易になるものと考 えられる。

\section{（5）固定端を有する連続ばりの自由振動}

a) 一端固定の場合 図一9 (a) 飞示す一端固定の連 続ばりの固有振動数 $\omega_{r}$ ・振動モード $\varphi_{\boldsymbol{r}}(x)$ を求めるこ とについて考光る。これには, 図一9(b) 飞示すように 固定端を単純支持飞置いた系について考光，この系に端 モーメント $M \sin \omega t$ を加兄て載荷点のたわ及角を0に する方法をとる。

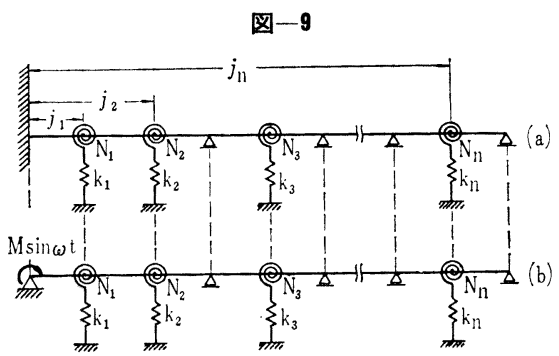

図一9 (b) の固有振動数 $\omega_{k}$ ・振動モード $\Phi_{k}(x)$ は （4）文）飞述べた方法により決定することができる。した がって，この振動モードを $x=0$ と扔いて角度が 0 にな るようと決定すればよい。端モーメント $M \sin \omega t$ が作 用するとき載荷点のたわ角角 $\theta\left(x_{i}=0\right)$ は式 (14) より 次式により求めることができる。

$$
\theta\left(x_{i}=0\right)=\sum_{k=1}^{\infty} \Omega_{k} \Phi_{k}\left(x_{i}=0\right) \Phi_{k}{ }^{\prime}\left(x_{j}=0\right) M
$$

ここに

$$
\Omega_{k}=1 /\left(\omega_{k}{ }^{2}-\omega^{2}\right)
$$

固定端飞扔いては $\theta=0$ であるから, 式 (37) は式 (38) となる。

$$
\sum_{k=1}^{\infty} \Omega_{k} \Phi_{k}{ }^{\prime}\left(x_{i}=0\right) \Phi_{k}{ }^{\prime}\left(x_{j}=0\right)=0
$$

式（38）は振動数方程式にほかならない。また振動モ一 ド $\varphi_{r}(x)$ は式 (38) 上り得られた $\omega_{r}$ の值を式 (13) 飞 代入すればただちに得られる。ただし, 式 (13) と捺け る $\Omega_{m}, \Phi_{m}(x)$ の代りと $\Omega_{k}, \Phi_{k}(x)$ を使用する。

b) 両端固定の場合 図一10 (a) 飞示す雨端固定の 連続ばりとついて考觉る。(5)a) と同じく図一10 (b) の系について考光, この両端に端モーメント $M_{A} \sin \omega t$, $M_{B} \sin \omega t$ を作用させる。このとき $\mathrm{A}, \mathrm{B}$ 点のたわ久角 $\theta_{A}, \theta_{B}$ は式 (39) 飞上り与兄れる。

図-10

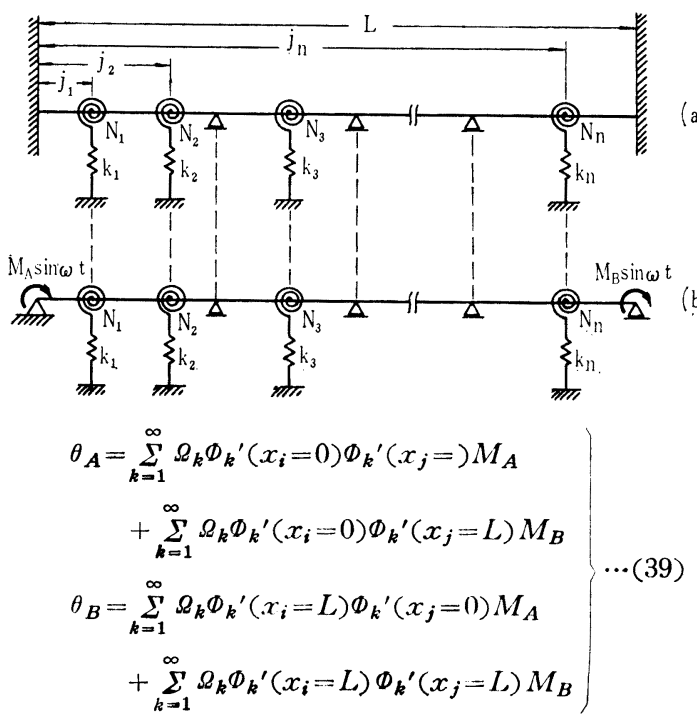

(a) 
固定端の場合 $\theta_{A}=\theta_{B}=0$ であるから式 (40) が得られる。

$$
\left.\begin{array}{c}
\sum_{k=1}^{\infty} \Omega_{k} \Phi_{k}\left(x_{i}=0\right) \Phi_{k}^{\prime}\left(x_{j}=0\right) M_{A}+\sum_{k=1}^{\infty} \Omega_{k} \Phi_{k}^{\prime}\left(x_{i}=0\right) \Phi_{k}{ }^{\prime}\left(x_{j}=L\right) M_{B}=0 \\
\sum_{k=1}^{\infty} \Omega_{k} \Phi_{k}\left(x_{i}=L\right) \Phi_{k}^{\prime}\left(x_{j}=0\right) M_{A}+\sum_{k=1}^{\infty} \Omega_{k} \Phi_{k}^{\prime}\left(x_{i}=L\right) \Phi_{k}{ }^{\prime}\left(x_{j}=L\right) M_{B}=0
\end{array}\right\}
$$

したがって振動数方程式は次式となる。

$$
\left|\begin{array}{ll}
\sum_{k=1}^{\infty} \Omega_{k} \Phi_{k}\left(x_{i}=0\right) \Phi_{k}^{\prime}\left(x_{j}=0\right) & \sum_{k=1}^{\infty} \Omega_{k} \Phi_{k}\left(x_{i}=0\right) \Phi_{k}{ }^{\prime}\left(x_{j}=L\right) \\
\sum_{k=1}^{\infty} \Omega_{k} \Phi_{k}\left(x_{i}=L\right) \Phi_{k}\left(x_{j}=0\right) & \sum_{k=1}^{\infty} \Omega_{k} \Phi_{k}{ }^{\prime}\left(x_{i}=L\right) \Phi_{k}{ }^{\prime}\left(x_{j}=L\right)
\end{array}\right|=0
$$

式 (41) を解いて求めた固有振動数 $\omega_{r},(r=1,2,3, \cdots \cdots$, の) の值を式 (40) 飞代入し, $M_{A}, M_{B}$ の比を決定し, こ れを式 (15) V代入すれば振動モード $\varphi_{r}(x)$ が決定でき る。ただし式 (15) と抢ける $\Omega_{m}, \Phi_{m}(x)$ には $\Omega_{k}, \Phi_{k}(x)$ を使用する。

\section{例 1 一端固定他端単純支持のはり}

例として 図一11 (a) 亿示す一端固定他端単純支持の はりの固有振動数を求めることについて考兄てみる。図 -11 (b) の単純ばりの固有振動数 $\omega_{m}$, 振動モード $\Phi_{m}(x)$

图-11

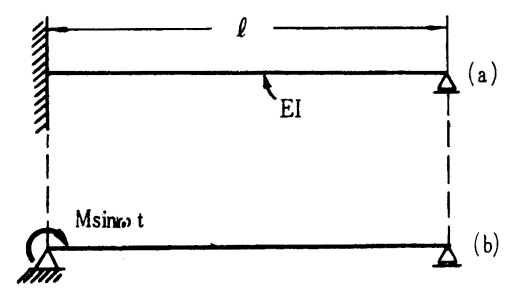

は式 (4)，(5)によりおらわされる。振動数方程式は式 （38）を使用すると式（42）となる。

$$
\sum_{m=1}^{\infty} \frac{m^{2}}{\omega_{m}^{2}-\omega^{2}}=0
$$

式（42）を書きかえると式 (43) となる。

$$
\sum_{m=1}^{\infty} \frac{m^{2}}{m^{4}-\omega^{\prime}}=0
$$

ここマ

$$
\omega^{\prime}=\omega^{2} /\left\{\left(\frac{\pi}{l}\right)^{4} \frac{E I}{\rho}\right\}
$$

式（43）を試算法により求めると, 最低次の固有振動数 として $\omega^{\prime}=2.4404$ が得られる。これは厳密解より得た 值帛と一致する。また, 振動モードはこの $\omega^{\prime}$ の値を式 (13) 亿代入すれば求めることができる。

\section{（6）多くの支承を持つ連続ばりの自由振動}

はりが多くの支承によって支持されているときには， この条件を同時に満足させるようにして式 (35) をたて ると数値計算が非常にはん雑になる。これを避ける方法 として (4) c 第 2 法に述へたように単純支持・変位・ 回転の条件を順次満足させることも数值計算を簡単にさ せる一方法であるが，ここでは下記の解析法について述 ヘう

図一12 (a) と示す連続ばりを例にとって考觉る。これ

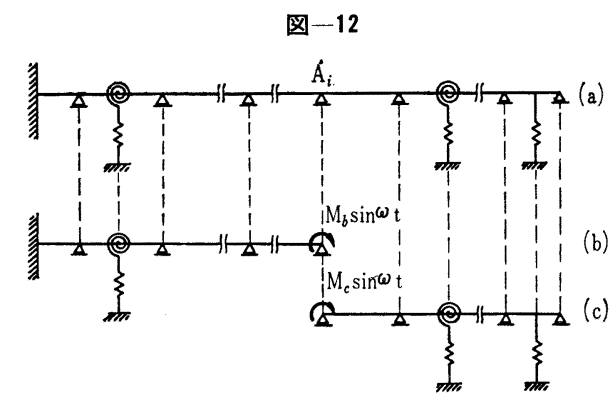

を適当な支持点 $A_{i}$ 点飞括いて切断し, 図に示す (b) 系・ (c) 系の 2 つの系にわける。まずこの (b),(c) 系の固有 振動数 $\omega_{b u}, \omega_{c u}$. 振動モ一ド $\Phi_{b u}, \Phi_{c u}$ を上述の適当な 方法に上り決定する。この (b), (c) 系の $\mathrm{A}_{\mathbf{i}}$ 点飞 $M_{b}$, $M_{c}$ なる周期モーメントを作用させた時この載荷点のた わ及角 $\theta_{b}, \theta_{c}$ 恃式 (14) とより下式にてあらわされる。

$$
\left.\begin{array}{rl}
\theta_{b} & =\sum_{u=1}^{\infty} \Omega_{b u} \Phi_{b u^{\prime}}\left(x_{b i}\right) \Phi_{b u^{\prime}}\left(x_{b, j}\right) M_{b} \\
\theta_{c} & =\sum_{u=1}^{\infty} \Omega_{c u} \Phi_{c u^{\prime}}\left(x_{c i}\right) \Phi_{c u^{\prime}}\left(x_{c j}\right) M_{c}
\end{array}\right\}
$$

この (b), (c) 系を結合すれば与系 ( $\mathrm{a}$ 図) ができるが, これを式で表現すると式 (44) の両者を等置することに なる。さらととのようにして組み立てられた原振動系に は, その結合点飞扔いて $M_{b}+M_{c}$ なるモーメント荷重 が作用しているので，前節と同様に自由振動時には外力 は0であるという条件より振動数方程式がつぎのように して得られる。

$$
\begin{aligned}
& \left\{\sum_{u=1}^{\infty} \Omega_{b u} \Phi_{b u^{\prime}}\left(x_{b i}\right) \Phi_{b u^{\prime}}\left(x_{b j}\right)\right\} \\
& \quad+\left\{\sum_{u=1}^{\infty} \Omega_{c u} \Phi_{c u^{\prime}}\left(x_{c i}\right) \Phi_{c u^{\prime}}\left(x_{c j}\right)\right\}=0 \cdots \cdots
\end{aligned}
$$

また振動モードは式 (45) より得られた固有振動数の值 を式（13）に代入すれれ゙ただちと決定できる。ただし式 (13) 中の文字 $m$ の代り飞 $b u$ または $c u$ を使用する必 要がある。

\section{3. 結 論}

上に述べたてとからわかるように，ここと結合法と名 うけけた解析法は，連続したはりと支承とにそれぞれ集中 荷重・モーメント荷重を作用させ,この変形したはりと支 承とを結合する方法である。弾性支承・固定端など複雑 
な条件を持つ連続ばりを解くにあたり，このような仮想 外力（集中荷重・モーメント荷重）を作用させながら固 有振動数・振動モードを決定する方法については他にな い上ろである。はりにモーメント荷重が作用するときそ の変形は，(2）飞扮いて述べたようにはりに集中荷重を 作用させたときのたわみ曲線をるととして解析できるの で，集中荷重をうけるはりのたわみ曲線が与兄られる限 りこの結合は可能である。

この問題をほかの方法例总ば振動たわみ角法によって 解くときには，まずこのはりを各スパンごとに支承点に 招いて切断し，このスパンの両端を支承に招いて結合す るという解析法を使用するから, 結合法上り複雑な考兄 方を必要とすることは明らかである。

結合法では，はりに結合する支承の順序は任意に変更 できるので，異なった種類の支承を持つはりに対して は, 同種の支承をグループにまとめ, これを順次結合す れば解析は簡単に行なうことができる。このように支承 をいくつかのグループにわけ, 各グループごとに結合す ることをくり返すと, 多くの未知数を同時仅り扱うこ となく数值計算を行なうことができるから便利である。 Digital 計算機を使用できる時代とはなったが，固有值 問題を取り扱う場合その行列の元数を減らすことができ ると静的問題とは比較にならぬほど計算時間を短縮でき ることを考光るとこの解析法の有利さがよく理解できる と思う。

前にも述べたよろに，この解析法によると振動モード を一つの解析関数としてあらわすことがでるので, 走 行荷重の動的レスポンスを求めるさい最初初期条件を与 えるだけで解が得られるから振動たわ及角法などにくら べて有利である。

ここでは固有振動数・振動モードを求めることのみに
ついて述べたが, 固有振動数・振動モードが決定できれ ば，任意の動荷重が作用するときそのレスポンスは式 （1）（2）または式（12）を用いていてただちに基礎式が 誘導できる。な招, 移動荷重が作用するときのレスポン スについては文献 4)を参照されたい。

この研究を行なうにあたり，いろいろご指導いただい た名古屋大学 成岡教授, 熊本大学 吉村教授に深く感 謝する次第である。

1）吉村・平井：ランガー桁の動的解析, 土木学会論文集, 101 号, 昭.39.1.

2）平井：結合法による格子構造の動的解析, 土木学会論文 集, 101 号, 昭.39.1.

3）例えば建築学大系 19 巻, p. 167.

4）平井：種々の移動荷重をうけるはり構造の基礎方程式と その応用, 土木学会論文集, 90 号, p. 29 , 昭.38.1.

5) Rogers, G.L. : Dynamics of Framed Structures, John Willy \& Sons, 1959, p. 263.

6) Saibel : Vibration Frequencies of Continuous Beams, Jour. of Aero. Sci., V. 11, p. 88, 1949.

7) Veletsos, A.S. \& N.M. Newmark: Determination of the Natural Frequencies of Continuous Beams on Flexible Supports, Proc. of Second U.S. Nat. Congr. of Appl. Mech., p. 147, 1954.

8) Bishop, R.E.D. \& D.C. Johnson: Vibration Analysis Tables, p. 49, Cambridge Univ. Press, 1956.

9) Bogunovic, V. : Der durchlaufende Balken auf äquidistanten elastischen Stützen, Ing. Arch., XXVII Bd., 1959, S. 104.

10) Lee, W.F.Z. and E. Saibel : Free Vibrations of Constrained Beams, J. of Appl. Mech., Vol. 19, 1952, p. 471.

11) 平嶋：多スパソ桁の振動数方程式, 土木学会論文集, 58 号, p. 102, 昭.33.9.

12）島田：バネ支承で支持された連続析の性質について，土 木学会論文集, 51 号, p. 51.

13）島田：バネ支承で支持された連続桁の解法，土木学会論 文集, 55 号, p. 57.

(1963.7.15 - 受付) 